\title{
El pueblo de Israel, Jesús y la Iglesia primitiva... ¿siempre en salida?
}

\author{
José Manuel Hernández Carracedo
}

RESUMEN: El artículo quiere presentar los relatos bíblicos que pueden servir de paradigma en este momento de la historia de la Iglesia. El pueblo de Dios ha sido llamado a «salir» de sí mismo como un camino pastoral y misionero. El trabajo recorre la historia de la salvación desde la creación hasta el inicio de la Iglesia de los orígenes exponiendo las distintas travesías del hombre, de Israel, de Jesús y los discípulos para que se puedan convertir de telón de fondo en el discernimiento a la hora de responder a esta llamada apremiante del Papa Francisco.

PAlABRAS ClAVE: Historia de la Salvación, Creación; Abraham, Éxodo, Destierro, Jesús y las fronteras, Discipulado, Iglesia de los orígenes.

ABSTRACT: The article wants to present the biblical stories that can serve as a paradigm at this time in the history of the Church. The people of God have been called to "come out" of themselves as a pastoral and missionary journey. The work traces the history of salvation from creation to the beginning of the early Church by exposing the different journeys of man, Israel, Jesus and the disciples so that they can become the backdrop for discernment in responding to this pressing call of Pope Francis.

KeYwords: History of Salvation, Creation; Abraham, Exodus, Exile, Jesus and the borders, Discipleship, Church of the origins. 


\section{Introducción}

El origen de este artículo se encuentra en una charla impartida en la Semana de Pastoral de Salamanca de 2019. La expresión «Iglesia en salida» se ha convertido en una gran luz para definir el camino pastoral y misionero impulsado por el Papa Francisco en esta hora de la Iglesia. Se debe recurrir a las fuentes bíblicas desde una perspectiva histórico-salvífica para iluminar esta apasionante llamada a todo el pueblo de Dios. Voy a presentar distintas «salidas», travesías que narra la Biblia. Son historias fundacionales y paradigmáticas: los momentos decisivos y definitorios de la identidad de Israel y de la Iglesia, porque proporcionan las claves para interpretar la historia posterior ${ }^{1}$. Este trabajo no quiere hacer una exégesis exhaustiva, sino un comentario en torno a las distintas «salidas» que pueden ayudar a definir la identidad de una Iglesia en salida, su pastoral y su presencia en el mundo.

\section{No tengáis miedo}

El primer día de la semana los discípulos estaban encerrados en casa (Jn 20,19). Tenían miedo. Se sentían fracasados y desilusionados. Ellos esperaban alcanzar junto a Jesús un puesto en la vida, «ser alguien». La oferta del Maestro les había seducido, pero también habían querido aprovecharse de la gracia para sus intereses. En las últimas etapas del camino y en el trance final sintieron el más hondo de los fracasos. No encontraron en Jesús lo que ellos esperaban ${ }^{2}$. A la hora de cenar Jesús se presentó en medio del grupo. El que les había llamado y acompañado. Al que los poderosos de este mundo habían condenado y crucificado, está vivo en medio de ellos con los brazos extendidos y las manos abiertas con las marcas de la cruz (Jn 20,20)3. Jesús aparece ante los discípulos como el Elevado, el que ha ido al Padre y les revela la existencia pospascual prometida

${ }^{1}$ Guijarro, Santiago, La primera evangelización (= Biblioteca de Estudios Bíblicos138), Sígueme, Salamanca 2013, 19.

${ }^{2}$ Legido, Marcelino, Misericordia entrañable. Historia de la salvación anunciada a los pobres, Sígueme, Salamanca 1987,16; Evangelii Gaudium 87.

${ }^{3}$ Legido, Marcelino, Misericordia entrañable, 17. 
en su último diálogo con ellos (Jn 14-17): es la aparición misma de la gracia, la revelación de la misericordia entrañable del Padre (Jn 1,14.17)

El encierro y el temor están motivados por «el miedo a los judíos». Esta situación refleja la experiencia del pequeño grupo expulsado de la sinagoga que vive en medio del mundo que les humilla y les persigue. Su saludo de paz disipa el miedo que les atenaza el corazón (Jn 20,21; cf. Jn 14,27). La existencia de los discípulos ya no está situada bajo el

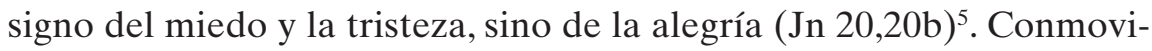
dos, contemplan el rostro, las manos y el costado en los que amanece la luz'.

Con la resurrección se abre un tiempo nuevo: el tiempo del envío, del don del Espíritu y del perdón (Jn 20,22-23) ${ }^{7}$. Alentados con el mismo amor, con que el Padre amó a Jesús, son incorporados a él. El encuentro se convierte en misión: han de irradiarlo al mundo. No pueden permanecer en casa con las puertas cerradas, sino salir a recorrer los caminos del mundo ${ }^{8}$.

Esta aparición del Resucitado es eficaz. Hace pasar a los discípulos del miedo y el encierro, a la alegría y a la asunción de una responsabilidad: ofrecer a todos los hombres la vida en plenitud ${ }^{9}$.

Desde el envío de la Pascua releemos la historia de la salvación. La Pascua es el centro del tiempo de la Historia de la salvación. De ella nace la misión de la Iglesia y en ella se unen la creación y la nueva creación. El «soplo» del Espíritu sobre los apóstoles, además de ser el Pentecostés joánico, es el inicio de la nueva creación, que impulsa a la Iglesia a una nueva salida: a reconocer cuanto ha sido amada desde el inicio (Ef 1,310) y a salir al mundo en una embajada misionera de misericordia y redención hasta el final de los tiempos, hasta la vuelta del Hijo, hacia la consumación (Col 1,12-20).

${ }^{4}$ ZuMstein, JeAn, El evangelio según Juan (13-21) (=Biblioteca de Estudios Bíblicos 153), Sígueme, Salamanca 2016,359; Legido, MARCELINo, Misericordia entrañable, 17.

${ }^{5}$ ZuMSTEIn, JeAn, El evangelio según Juan (13-21), 360.

${ }^{6}$ Legido, MARCelino, Misericordia entrañable, 17.

${ }^{7}$ Zumstein, JeAn, El evangelio según Juan (13-21), 361.

${ }^{8}$ Legido, Marcelino, Misericordia entrañable,18-19; Evangelii Gaudium 23.

${ }^{9}$ Zumstein, JeAn, El evangelio según Juan (13-21), 364. 


\section{La salida primordial}

La creación entera ha salido de las manos del Padre. El hombre está llamado a una doble salida: hacia Aquel en el que se sustenta y hacia lo que se le ha dado: la casa común (el mundo) y la familia humana.

En el primer capítulo del Génesis, Dios crea separando. Lo contrario de la creación es el caos, el desorden. En la separación es como las creaturas pueden asumir su identidad, su verdadero ser. El hombre es hombre en la medida que acepta su diversidad respecto de las cosas, de los demás hombres y de Dios. Es la diversidad lo que le define como un «ser en comunión ${ }^{10}$. La distinción no es enfrentamiento, afirmación de uno frente a otro, sino necesidad de uno para otro. Solo en comunión el hombre puede ser y caminar ${ }^{11}$. Quien reniega de la alteridad, reniega de la creaturalidad, reniega de ser verdaderamente hombre.

La imagen del Padre en nosotros es capacidad de ser, de decidirse, de darse ${ }^{12}$. Esto se hace explícito en el segundo relato de la creación del hombre y de la mujer. El Señor Dios se dijo: «No es bueno que el hombre esté solo; voy a hacerle a alguien como él, que le ayude» (Gen 2,18). Al ser creada la mujer exclamó Adán: « Esta sí que es hueso de mis huesos y carne de mi carne! Su nombre será "mujer" (isah), porque ha salido del varón (ish)» Por eso abandonará el varón a su padre y a su madre, se unirá a su mujer y serán los dos una sola carne» (Gen 2,23-24). Es la primera vez que escuchamos la voz del ser humano en la Biblia, y oímos una palabra de reconocimiento de la que es distinto de él, reconociendo su igualdad. Una palabra de comunión y de encuentro ${ }^{13}$.

El texto da el verdadero sentido de qué y quién es la persona: una paradoja. El hombre es una realidad carencial, en su vivir, en su crecer y en su desarrollo tiene que integrar esta carencia radical por medio de la

${ }^{10}$ Von Rad, Gerhard, El libro del Génesis (=Biblioteca de Estudios Bíblicos 18), Sígueme, Salamanca 1988, 71; Ruiz de la PeÑa, JuAn Luis, Teología de la creación (=Presencia Teológica 24), Sal Terrae, Santander 1987, 42.

${ }^{11}$ Legido, MARCELINo, Misericordia entrañable. Historia de la salvación anunciada a los pobres, Sígueme, Salamanca 1987, 58.

${ }^{12}$ Legido, MARCELINo, Misericordia entrañable. Historia de la salvación anunciada a los pobres, Sígueme, Salamanca 1987, 55; Evangelii Gaudium 39.

${ }^{13}$ Ruiz de la Peña, JuAn Luis, Antropología teológica fundamental (=Presencia teológica 49), Sal Terrae, Santander 1988, 35. 
acogida de la alteridad. El hombre necesita a otro (persona, Dios) con quien compartir, reconociéndose en él, compartiendo el ser y el camino desde lo que son: gracia y amor ${ }^{14}$. El ser humano para ser en plenitud está llamado a salir de sí mismo y unirse a otro formando una nueva realidad ${ }^{15}$.

«Estar solo» no es lo mismo que «ser uno solo». Lo primero supone renuncia a la comunión, lo segundo es una común-unión que integra la diversidad.

\section{La salida del Paraíso}

En su salida el hombre se vuelve hacia sí mismo. Tras el pecado, el hombre debe abandonar el Edén, pero no pierde la gracia. En esta salida Dios le revela la necesidad de «salir», de no cerrarse en sí mismo para salvarse. Esto aparece en los famosos «castigos bíblicos» que no son tales. Dios simplemente está diciendo cuáles son las consecuencias del mal que ya se ha producido, porque es el mal el que castiga al hombre ${ }^{16}$.

Cuando Dios interviene incluso el camino del hombre pecador señalado por el miedo, la opresión, el dolor y la muerte se convierte en camino para salir de sí mismo y salvar su vida. El texto debe entenderse simbólicamente ya que presenta las consecuencias del pecado tomando los dos lugares típicos en los que el hombre y la mujer se asemejan más a Dios: dar a luz y trabajar ${ }^{17}$.

Dios vuelve a dirigirse a sus creaturas. A la mujer le dijo: «Mucho te haré sufrir en tu preñez, parirás hijos con dolor, tendrás ansia de tu marido, y él te dominará» (Gen 3,16). Por un lado, está diciendo que las relaciones con la vida han sido alteradas, pero por otro, este dolor, misteriosamente, le ayudará a no engañarse a sí misma pensando que puede ser como Dios al dar vida, le revela, que necesita a otro. En su debilidad buscará la ayuda del varón, en cambio el fuerte, en lugar de inclinarse hacia la debilidad para ayudarla, usará su fuerza para dominarla. Entonces, la debilidad de la mujer le permite abrirse a Dios, el único fuerte que salva sin oprimir.

\footnotetext{
${ }^{14}$ Legido, Marcelino, Misericordia entrañable, 57.

${ }^{15}$ Ruiz de la Peña, JuAn Luis, Antropología teológica fundamental, 46.50.

${ }^{16}$ Ruiz de la Peña, JuAn Luis, El don de Dios. Antropología teológica especial (=Presencia Teológica 63), Sal Terrae, Santander 1991, 66-67.

${ }^{17}$ Von Rad, Gerhard, El libro del Génesis, 112-113.
} 
A Adán le dijo: «Por haber hecho caso a tu mujer y haber comido del árbol del que te prohibí, maldito el suelo por tu culpa: comerás de él con fatiga mientras vivas; brotará para ti cardos y espinas, y comerás hierba del campo. Comerás el pan con sudor de tu frente, hasta que vuelvas a la tierra, porque de ella fuiste sacado; pues eres polvo y al polvo volverás» (Gen 3,17-19). Cuando el hombre trabaja se asemeja al Dios creador. Pero si crea con sudor, ya no puede engañarse creyendo que es Dios. Si aún se engañase pensando que es todopoderoso porque domina a los otros, entonces aparece la muerte. Ante la muerte no hay posibilidad de engaño. Así paradójicamente, la muerte se convierte en la oportunidad definitiva para abrirse a Dios y ser salvado.

El hombre y la mujer, al ser expulsados del jardín entran en una nueva historia y en una nueva relación con el mundo, marcadas por el mal. En esta historia, Dios los acompaña. Los que estaban desnudos salen vestidos por Dios (Gen 3,21) ${ }^{18}$. Las prendas dicen que han pecado, porque si no hubiesen pecado no habría necesidad de ropa, pero a la vez, señalan que este pecado Dios puede y quiere sanarlo, que Dios entra en la realidad del pecado para transformarlo en un lugar de perdón, amor y gracia.

Toda la historia de la salvación es una salida del padre hacia su pueblo y su creación. A continuación describiremos tres «salidas»: la de Abrahán, salida en la obediencia en la fe; la del Éxodo, salida de la esclavitud a la libertad; y la del destierro, salida del bienestar a la pequeñez sostenida por el Señor.

\section{La salida de Abrahán}

Existe una doble tradición sobre el lugar de origen de Abrahán: Jarán y Ur. Son lugares distintos y demasiado distantes como para unificarlos. Los dos se pueden considerar el punto de partida de su viaje ${ }^{19}$. El texto está organizado de modo que la llamada de Abrahán se encuadra dentro de una partida que ya ha tenido lugar: la salida de Ur. En Gen 12,1 se le pide partir nuevamente. Cuando Dios le pide que salga, Abrahán ya ha partido, ya era un emigrante. No cambia ni siquiera su itinerario, porque a donde le dice que vaya, ya está yendo.

${ }^{18}$ Von Rad, Gerhard, El libro del Génesis, 116.

${ }^{19}$ Von Rad, Gerhard, El libro del Génesis, 190. 
Cuando Dios llama a un hombre (o a un grupo) a una vocación particular, lo hace siempre dentro de un camino que ya ha comenzado. En el momento en el que Dios aparece, el hombre se comprende dentro de su propio camino y su propia historia. El hombre reconoce que, en realidad, Dios estaba en el origen de la llamada.

La primera partida de Abrahán es una emigración determinada por situaciones históricas y sociológicas. Cuando parte por segunda vez, su salida es totalmente distinta. No es una emigración normal, sino que se transforma en un evento que salvará al mundo y que cambia la maldición en bendición. Canaán no es solo una tierra para buscar nuevos pastos, sino la Tierra Prometida. Sara ya no será la estéril, pues al que no tenía hijos le constituye en padre de una multitud de pueblos.

Esta salida transforma la historia del hombre en historia de salvación, y se realiza de forma paradójica ${ }^{20}$. Abrahán es llamado a recibir la bendición y hacerse él mismo bendición para todos, pero su situación es de total maldición: no tiene hijos; se va a otra tierra que no es la suya; tiene riquezas que se convierten en fuente de conflictos, por su causa se debe separar de Lot (Gen 13,7).

La orden de Dios lo hace extranjero para siempre. Al sacarle de su tierra de origen, Dios le promete otra tierra, pero va a un país que no es suyo y que jamás podrá serlo: siempre estará detrás de los oriundos del lugar, sin derechos, sin tutela: en el último puesto.

Así son las llamadas y las promesas de Dios en la historia: sus dones, para que lo sean, es necesario que sean cosas que uno no puede poseer. Porque si lo posees es tuyo, ya no son de Dios, y no sirven a nadie. Para que el don de Dios pueda servir es necesario que se acoja, pero sin apropiárselo. Es necesario que Abrahán posea la tierra, pero sin apropiársela; que sea bendito, pero dentro de la aparente maldición.

¿Qué hace Abrahán al llegar a la tierra y ver que nada de lo que se le ha prometido aparentemente es verdad? El Señor se apareció a Abrán y le dijo: «A tu descendencia daré esta tierra». Él construyó allí un altar en honor del Señor que se le había aparecido (Gen 12,7). Abrahán será causa de bendición porque en la maldición no ha maldecido a Dios, sino que lo ha bendecido levantando un altar. Entrando en la maldición confiesa que Dios es bueno y así la maldición se transforma en bendición.

${ }^{20}$ VON RAD, Gerhard, El libro del Génesis, 193-194. 


\section{La salida de Egipto}

Nada más salir de Egipto, Israel se encuentra en una situación que parece desmentir la promesa de Dios. Ha escapado de Egipto para ser el pueblo de Dios, pueblo libre y soberano en una tierra que les perteneciese. Ahora se encuentra rodeado por dos fuerzas hostiles, dos monstruos: delante, el mar; detrás, Egipto. La promesa de Dios es falsa o Dios la ha retirado. Esta es la cuestión que trata el relato del paso del Mar Rojo (Éx 14), el de la fe que se pone a prueba cuando los acontecimientos desmienten las promesas de Dios.

Israel se encuentra ante el mar, signo del caos y de la muerte. No hay camino en el mar. Tras Israel, está Egipto con toda su potencia. ¿Qué hace Israel?

El pueblo grita. Dijeron a Moisés: «¿No había sepulcros en Egipto para que nos hayas traído a morir en el desierto?; ¿qué nos has hecho sacándonos de Egipto? ¿No te lo decíamos en Egipto: "Déjanos en paz y serviremos a los egipcios, pues más nos vale servir a los egipcios que morir en el desierto?"” (Gen 14,11-12). Es una queja que acusa a Dios mismo. Un grito que se distancia del camino de vida y libertad y que siente nostalgia de Egipto, un país de sepulturas. Prefieren Egipto al desierto, la esclavitud a la libertad, el mundo conocido del Faraón al mundo desconocido de una aventura con Dios ${ }^{21}$. Ellos esperaban una libertad regalada pero no comprometida ni padecida arriesgándose a la muerte ${ }^{22}$. El miedo a morir les conduce al pasado. Israel prefiere, guiándose por su mentalidad de esclavo, la muerte en vida. Su angustia se expresa en el grito que acusa a Moisés y a Dios. Dios nos ha engañado, prometiéndonos un camino de vida y por el contrario los acontecimientos dicen que el camino de Dios es un camino de muerte. Pero Israel habla de morir en el desierto, sin darse cuenta de que su temor nace de los egipcios que les persiguen y los matarán si no aceptan la esclavitud. A causa del miedo, la realidad se confunde y el juicio se nubla, haciendo estallar un instinto de conservación que no distingue entre la vida biológica y la verdadera existencia humana.

${ }^{21}$ SKa, JeAn Louis, El camino y la casa. Itinerarios Bíblicos, Verbo Divino, Estella 2005,36 .

${ }^{22}$ Legido, MARCELino, Misericordia entrañable, 132. 
Y así prefieren permanecer vivos, renunciando a la vida ofrecida por $\operatorname{Dios}^{23}$.

El pueblo se encuentra ante un cruce de señoríos: someterse al faraón o acogerse al Señor. Hay que romper el miedo y la angustia, creer en su amor y abandonarse (Is 30,15). Si el pueblo acoge la liberación del Señor se pondrá en marcha desplegando la energía de Dios en él, y las sendas serán más hondas y más anchas, de lo que ellos esperaban (Ex 14,22.29; 15,2.3.12-13; Dt 32,6) $)^{24}$.

Moisés respondió al pueblo: «No temáis; estad firmes y veréis la victoria que el Señor os va a conceder hoy: esos egipcios que estáis viendo hoy, no los volveréis a ver jamás. El Señor peleará por vosotros; vosotros esperad tranquilos» (Ex 14,13-14). La intervención de Moisés apela a la fe. No a una respuesta operativa, programada, diseñada o falsamente ilusoria, sino a la fe que entra en la impotencia, para asumir con plenitud la potencia y la acción de Dios: dejar que Dios actúe. Hay que ir por un camino que no se ve atravesando el mar: Dios va a actuar, no se sabe cómo, ni dónde... pero actúa ${ }^{25}$.

Dios combate e indica el camino a través de las aguas. Israel sale de la tierra firme y entra en el mar. Es el mismo Señor a la cabeza de su pueblo, camino de la tierra de la herencia, el que hace camino (Ex14, 17.18). Es el Señor con sus entrañas de misericordia, el que toma de la mano a la pequeña y pobre familia de sus hijos, que está en la esclavitud, para arrancarle las cadenas y conducirla a la mesa de la tierra prome$\operatorname{tida}^{26}$.

Israel realiza una travesía pascual. Comienza al amanecer (Ex 14,9), camina de noche (Ex 14,20-21) y acaba al amanecer (Ex 14,27); se encamina desde el ocaso (oeste) hasta el amanecer (este); desde las tinieblas a la luz; de la esclavitud a la libertad ${ }^{27}$.

Israel atraviesa el mar, el mundo ambiguo, peligroso, hostil, indómito, símbolo del caos y de la muerte. Los egipcios son devorados porque son

${ }^{23}$ Costacurta, Bruna, La vita minacciata. Il tema della paura nella Bibbia Ebraica (=Analecta Biblica 119), Editrice Pontificio Istituto Biblico, Roma 1997, 100-101.

${ }^{24}$ Legido, Marcelino, Misericordia entrañable, 132.

${ }^{25}$ Cf. Evangelii Gaudium 85-86.

${ }^{26}$ Legido, MARCELINO, Misericordia entrañable, 130.

${ }^{27}$ SKa, JeAn Louis, El camino y la casa, 30-31. 
ciudadanos del mundo de la violencia, la opresión y la muerte ${ }^{28}$. Esta victoria total y definitiva de Dios señala la definitiva liberación de Israel. Con el fin de la batalla entre Dios y el faraón cesa el miedo de Israel y su nostalgia de la esclavitud y puede entrar en una vida completamente nueva ${ }^{29}$. El pueblo sale del miedo y entra en el temor de Dios (Ex 14,30-31) ${ }^{30}$. El grito blasfemo se convierte en canto de alabanza: «Cantaré al Señor, pues se cubrió de gloria, caballos y jinetes arrojó en el mar» (Ex 15,21). El pueblo que contempla el alba es un Israel transformado, transfigurado, regenerado por su experiencia ${ }^{31}$. Israel ha quedado purificado de su mentalidad "egipcia y "faraónica” y resurge renovado como pueblo del Señor ${ }^{32}$.

\section{El retorno del Exilio}

Especialmente significativa es la narración de la salida de Babilonia. La vuelta del exilio es mucho más que un simple retorno a la patria. El Libro de la Consolación de Jeremías (Jer 30-31) es la cumbre del mensaje de esperanza de su profecía. El Señor se dirige a los «supervivientes» de Israel para anunciar un nuevo éxodo y una peregrinación a Sión, que inaugura una era de alegría y bienestar ${ }^{33}$.

Los judíos en Babilonia se habían situado bien, aunque mantenían su fe, se habían insertado profundamente en los engranajes socioeconómicos y políticos del imperio. A la hora de "salir" muchos de ellos no querían dejar sus posesiones (Jos., Ant 11,1.3). Solo un pequeño resto salió ${ }^{34}$. Veamos más de cerca la peregrinación ${ }^{35}$ :

«Gritad de alegría por Jacob, regocijaos por la flor de los pueblos; proclamad, alabad y decid: ;Salva, Yahveh, a tu pueblo, al resto de Israel!'Los traeré del país del norte, los reuniré de los confines de la tierra. Entre ellos habrá ciegos

\footnotetext{
${ }^{28}$ SKa, JeAn Louis, El camino y la casa, 33.

${ }^{29}$ Costacurta, Bruna, La vita minacciata, 103.

${ }^{30}$ SKa, JEAn Louis, El camino y la casa, 27.

${ }^{31}$ SKa, JeAn Louis, El camino y la casa, 23. Es la misma experiencia del bautismo que se expresa en Rom 6,1-14.

${ }^{32}$ Ska, JeAn Louis, El camino y la casa, 37.

${ }^{33}$ Alonso SchöKel, Luis - Sicre, Jose Luis, Profetas, Cristiandad, Madrid 1987,

${ }^{34}$ Legido, Marcelino, Misericordia entrañable, 196.

${ }^{35}$ Las cursivas son traducción propia.
} 558. 
y cojos, lo mismo preñadas que paridas: Gran asamblea vuelve acá. Vendrán todos llorando y yo los guiaré entre consuelos; los llevaré a torrentes de agua, por camino llano, sin tropiezos. Porque yo soy para Israel un padre, y Efraín es mi primogénito» (Jer 31,7-9).

Encontramos algunas expresiones chocantes en el texto. En el versículo 7, el Señor invita al pueblo a alegrarse: Porque esto dice el Señor: «Gritad de alegría por Jacob, regocijaos por la flor de los pueblos; proclamad, alabad y decid: ¡Salva, Yahveh, a tu pueblo, al resto de Israel!» Si se eleva una alabanza debería decir: "el Señor ha salvado a su pueblo". En el texto aparece una súplica ("salva, Señor, tu pueblo"). La petición de una salvación que todavía debe llegar, y que a la vez ya ha llegado y se ha experimentado, porque el pueblo vuelve del exilio. La alabanza se articula con la súplica, porque la alabanza del hoy, lo es por un evento histórico, pero que es promesa y anticipación de la salvación definitiva. No es ya la súplica de quien está en el exilio, en la oscuridad, y no experimenta la salvación y debe tan solo esperarla, sino que es la súplica de quien no necesita esperar más la salvación -porque la está experimentando- y esto lo proyecta en una salvación definitiva. Aquel que hoy puede alabar a Dios, porque Dios salva, se convierte en testigo, mediador e intercesor de la salvación futura.

Esta es la paradoja de la historia de Dios con los hombres, toda etapa de la salvación reenvía a una sucesiva.

Este retorno es signo de que se ha terminado la alienación del pueblo que había perdido su identidad. El pueblo tiene que pasar por la experiencia fundacional del Éxodo, que es la experiencia de la liberación y de vencer las amenazas. Allí se experimenta el amor de Dios ${ }^{36}$.Y este pequeño resto que vuelve se convertirá en una gran asamblea.

El versículo 8 dice: «Gran asamblea, vuelve acá». Vuelven a la patria y al templo del Señor el ciego, el cojo, la embarazada y la que ha dado a luz. Todos ellos vuelven con dificultad y caminan fatigosamente: el ciego porque no ve, el cojo porque tiene problemas para desenvolverse, la embarazada por el peso del niño que lleva y la parturienta porque se ha debilitado por el parto. Precisamente aquellos que por ser impuros no podrían entrar en el Templo son aquellos que vuelven.

${ }^{36}$ Alonso SchöKel, Luis, - Sicre, Jose Luis, Profetas, 559. 
No es un grupo de personas fuertes, sino un pueblo débil en el que se puede manifestar la fuerza de Dios y donde se puede descubrir la salida de Babilonia como gracia. En este grupo se sintetiza dolor y fecundidad: la preñez que estorba el caminar y es prenda de futuro, el parto que atenaza con su dolor y suelta redoblando el gozo. Las mujeres llevan dentro de sí el resto, la sucesión ${ }^{37}$.

Vuelven en el llanto y en la súplica: «Con lloro vienen y con súplicas los devuelvo, los llevo a arroyos de agua por camino llano, en que no tropiecen». De nuevo la paradoja, antes la alabanza estaba articulada con la súplica, ahora la alegría está articulada con el llanto. El retorno del exilio es en realidad retorno a Dios, que es fundamentalmente conversión, que precisa el llanto y que se abre a la súplica ${ }^{38}$.Vuelven llorando y suplicando, pero todo esto es gracia y misericordia.

Esto se hace evidente en el v. 9: «Porque yo soy para Israel un padre, y Efraín es mi primogénito». Es la fórmula típica de la alianza, pero con la indicación particular de que Efraín es el primogénito. Aunque Efraín es el segundo, el hermano menor.

Es la elección del Dios de los pequeños y de los débiles. La raíz de todo está en el amor eterno de Dios que se traduce en lealtad a lo largo del tiempo y en favor en el momento dado ${ }^{39}$. Dios definitivamente se convierte en padre y el pueblo definitivamente se convierte en hijo. Es la alianza con el pequeño, que en modo absolutamente gratuito no solo retorna a la patria, sino que en este camino de vuelta hace experiencia del retorno a Dios que es gracia sobreabundante, que supera el exilio, que vence el pecado, que triunfa definitivamente sobre la muerte.

El texto continúa con la gran visión del pueblo reunido: «vendrán y cantarán himnos en torno a Sión». Retornarán al Templo donde todos se alegrarán, el luto se cambiará en alegría y el pueblo se saciará de los bienes de Dios. Se ve que este retorno a la patria es retorno a Dios. En esta vuelta se cumplen todas las promesas, porque serán reedificados Jerusalén y el templo, allí será posible encontrar de nuevo a Dios. Retornar del exilio es anticipar el retorno al Señor, verdadero cumplimiento de este retorno a Jerusalén y al Templo reedificado.

\footnotetext{
${ }^{37}$ Alonso Schökel, Luis, - Sicre, José Luis, Profetas, 561.

${ }^{38}$ Evangelii Gaudium, 25-26.30

${ }^{39}$ Alonso Schökel, Luis, - Sicre, José Luis, Profetas, 559.
} 
Estamos en el ya (el retorno a la patria) pero en el todavía no (porque este retorno a la patria es promesa de otro retorno). Ya se experimenta el volver a Dios, que es lo importante; pero todavía hay que esperar, porque ese volver a Dios será definitivo solo en la escatología. La salida histórica se convierte en signo del cumplimiento definitivo en el futuro.

El nuevo éxodo es una salida de la idolatría y de la injusticia (Is 62,1012). El Señor lo hará por la mano de su Ungido (Is 61,1-2). En realidad, a donde se encamina no es a restaurar el Templo y las murallas de la ciudad, sino a otra ciudad nueva, la nueva Jerusalén en donde se congregarán todos los pueblos de la tierra. El Señor con su pequeño resto (Is 24, 1315a) va a realizar su victoria, y la gran señal será el monte convertido en mesa para compartir (Is 25,6-8) donde están invitados todos, sobre todo los pobres. Vamos hacia la nueva ciudad del pueblo nuevo (Is 60,1-3) ${ }^{40}$. Un triunfo que se hace realidad en el misterio pascual del Señor Jesús: en su «paso» al Padre.

\section{La salida al Padre}

El Hijo salió del Padre y vuelve al Padre, habiéndonos amado hasta el extremo. Su salida es paradigma permanente para la Iglesia (Flp 2,6-11).

«Antes de la fiesta de la Pascua, sabiendo Jesús que había llegado su hora de pasar de este mundo al Padre, habiendo amado a los suyos que estaban en el mundo, los amó hasta el extremo» (Jn 13,1). El Padre lo envió a dar su amor a sus hijos divididos y enfrentados. Si los hermanos están en la brecha de la muerte, hasta allá hay que llegar. Porque todas las esclavitudes se concentran en la muerte. Por eso el exceso de amor es abrazar la muerte, llevar la gratuidad hasta la muerte.

Jesús entra en la conflictividad de la historia con mansedumbre y humildad de corazón, revelando el amor misericordioso del Padre, obedeciendo su encargo y poniéndose en sus manos. Se entrega a los hermanos como esclavo y les parte el pan, para hermanarlos, sellando la nueva y definitiva alianza en su cuerpo entregado y su sangre derramada en la cruz. Donde la gracia aparece como debilidad y como impotencia. Una vez más la paradoja. Parece que la muerte ha destruido

${ }^{40}$ Legido, Marcelino, Misericordia entrañable, 201. 
a la vida, que el pecado ha vencido al amor, el dolor a la gracia, la injusticia a la justicia, la opresión a la libertad, la mentira a la verdad. Pero el sepulcro vacío es una brecha abierta en el muro de la muerte. La resurrección es la victoria de la gracia. Es la entronización a la derecha del Padre que a los ojos de Juan ya se ha producido en la cruz misma: «Y cuando yo sea elevado sobre la tierra, atraeré a todos hacia mí. Esto lo decía dando a entender la muerte de que iba a morir» (Jn 12,32-33). En la cruz se manifiesta la gloria, la gracia y la verdad, la misericordia y la fidelidad del Padre con nosotros.

La pascua de Jesús es la última y definitiva salida que lleva a plenitud al hombre y a la creación. Salida a la que estamos provocados todos: “Así pues, salgamos donde él, fuera del campamento, cargando con su oprobio, que no tenemos aquí ciudad permanente, sino que andamos buscando la del futuro" ( $\mathrm{Hb} 13,13-14)$.

\section{9.- Salir por sus mismas huellas}

Jesús habitualmente caminaba por las fronteras: «Una vez, yendo camino de Jerusalén, pasaba entre Samaría y Galilea» (Lc 17,11). La salida de los cristianos debe ser siempre en sus mismas huellas: saliendo a la otra orilla, atravesando fronteras para encontrarse con la sed del hombre como discípulos desprendidos y valientes.

\section{Jesús sale a la otra orilla}

En una dura travesía con viento contrario, Jesús se acerca a tierra pagana. Una salida al encuentro de los alejados ${ }^{41}$. Allí se encuentra con un endemoniado. Una víctima del mal, engullido por el sufrimiento. Vive aislado en un lugar desértico (el demonio de la soledad), en un lugar impuro, excluido de las demás personas (el demonio de la marginación y la muerte en vida), pasa las noches y los días gritando (lunático), se autolesiona y se autodestruye: el mal le conduce a la muerte. Perdido el control de sí mismo se encuentra a merced de las fuerzas del mal que le poseen. Al endemoniado nadie puede controlarle, encadenarle no sirve de nada, solo aumenta

${ }^{41}$ Marcus, Joel, El evangelio según Marcos (Mc 1-8) (=Biblioteca de Estudios Bíblicos 130), Sígueme, Salamanca 2010,392. 
su violencia. Paradójicamente a un encadenado por el mal, los hombres intentan encadenarlo aún más (Mc 5,2-5) ${ }^{42}$.

El endemoniado intenta exorcizar a Jesús, el mal se resiste a abandonar su conquista, regatea con él y le increpa. En cambio, Jesús entra en diálogo con el poseído, quiere conocer su nombre, la naturaleza exacta de su mal y de su sufrimiento. El nombre «Legión» pone de relieve la gran magnitud y el poder del mal. Hay que conocer el mal para sanarlo y erradicarlo para siempre (Mc 5,7-9).

Sobrecogidos por lo ocurrido los ciudadanos, muestran su rechazo a Jesús: ¿Se ha convertido en una amenaza? ¿Descubren en Jesús la obra del mal? ¿Temen por sus posesiones económicas? ¿Prefieren sus cerdos a un hombre sentado, vestido y en su sano juicio? (Mc 5,14-17) ${ }^{43}$.

El antiguo endemoniado pide convertirse en discípulo. Jesús no lo retiene junto a sí. Le envía a su casa, a los suyos, a su ambiente. Se convierte así en un heraldo del evangelio allí donde se encuentra, aunque sea un territorio hostil, porque no se olvidará fácilmente que era un endemoniado $(\text { Mc 5,18-20) })^{44}$.

\section{La salida a Samaría}

Al comienzo del capítulo cuarto el narrador del evangelio de Juan comenta el itinerario de Jesús desde Jerusalén a Galilea (Jn 4,3) presentando su paso por Samaría como inevitable: «Era necesario que él pasara a través de Samaría» (Jn 4,4).

Pero esto no es estrictamente cierto. De hecho, la ruta más cómoda y habitual es a lo largo del valle del Jordán. De esta forma se evita la ruta montañosa y el incómodo contacto con los samaritanos. Esta anotación geográfica puede leerse en un doble sentido. En primer lugar, explica el paso obligado de aquel que se traslada directamente y sin rodeos desde Judea a Galilea, así la nota disculpa el paso de Jesús por Samaría $(\mathrm{Jn} 4,9)$ que había llamado la atención de los fariseos y se aleja rápidamente (Jn 4,1).

${ }^{42}$ Marcus, Joel, El evangelio según Marcos (Mc 1-8),392.401-402; GuiJarro, SanTIAGO, "La dimensión política de los exorcismos de Jesús" en Estudios Bíblicos 58 (2000) 51-77, p.77.

${ }^{43}$ Guijarro, Santiago, "La dimensión política de los exorcismos de Jesús", 68.

${ }^{44}$ Marcus, Joel, El evangelio según Marcos (Mc 1-8),407. 
En un nivel más profundo, la nota coloca este trayecto dentro del plan del Padre al utilizar el término (era necesario), que también aparece en los anuncios de la pasión y en el relato de Emaús (Mc 8,31 par.; Lc $24,26)$. Jesús desborda las fronteras del «verdadero Israel» por una «necesidad» divina e inscribe su revelación en un espacio heterodoxo y sincretista.

Jesús es aquel que sigue el plan divino. Unido a Dios, en permanente obediencia, traspasa las barreras sociales, de raza, religiosas y de género. El acceso a la fe de los samaritanos no se basa en los signos de Jesús, ni en las afirmaciones de la Escritura, sino en la búsqueda profunda del corazón del hombre simbolizado en la samaritana. El descubrimiento progresivo de la identidad de Jesús es la respuesta a esa búsqueda.

\section{Por los Caminos del Espíritu: Felipe y Pedro}

La salida misionera de la iglesia de los orígenes no se debió a una programación diseñada por los apóstoles. Para ellos significó una auténtica conversión, tuvieron que reconocer la actuación del Espíritu que desbordaba sus cálculos y rompía sus esquemas. Veamos dos ejemplos: Felipe y Pedro.

El primero, judeo-helenista, se traslada a Samaría. La fuerza de los acontecimientos (persecución) y su convicción interior le han llevado a franquear las puertas que no solo estaban cerradas, sino incluso prohibidas. El evangelizador no es un funcionario, pero tampoco es un francotirador, una decisión tan importante es avalada por los apóstoles de Jerusalén, produciéndose el pentecostés de los samaritanos (Hch 8,14-17).

Más adelante, el Espíritu cambia sus planes y le dirige hacia Gaza en el momento más caluroso del día y cuando todo está desierto. En el camino se encuentra con un eunuco etíope (Hch 8,27) que ha ido a adorar a Jerusalén, pero está excluido del culto del Templo. Felipe debe acercarse, ponerse junto a él para saber lo que lleva dentro, escuchar, y subirse al carro del otro. Cambia Felipe y cambia el etíope ${ }^{45}$.

${ }^{45}$ Aguirre, Rafael, "Los caminos del Espíritu: Felipe, Pedro y Pablo" en SARMIENTo, P.M. - Grosso, L. (eds.), No apaguéis el Espíritu. Nuestra casa encendida, Publicaciones Claretianas, Madrid 1998, 85-114, 89. 
En segundo lugar, al narrar el encuentro de Pedro con Cornelio se describe la conversión del primero. Pedro es un judío relativamente flexible, reside en Jope, una ciudad pagana, hospedado en la casa de Simón el curtidor, oficio impuro para la ortodoxia judía. Es el Espíritu el que le acerca a los paganos. Pese a su resistencia (Hch 10,28) Pedro anuncia el evangelio a Cornelio y a toda su casa, y, algo más, se hospeda con ellos (Hch 10,48). El Espíritu conduce a la superación de la barrera de la pureza y la impureza, de judío y griego. Asistimos a la mayor innovación histórica de la Iglesia primitiva ${ }^{46}$.

El Espíritu desestabiliza las cómodas rutinas, convulsiona equilibrios y convenciones arraigadas, porque continuamente abre a perspectivas más amplias y síntesis más ambiciosas.

Para escuchar al Espíritu hay que escuchar al otro, sobre todo al otro diferente, al que nos puede des-identificar porque tiene algo nuevo que decirnos. En él está el origen de las sendas más innovadoras para construir una Iglesia acogedora y universal y al mismo tiempo impulsa siempre a mantener la comunión con los hermanos que más dificultades pueden tener para comprender las nuevas fronteras que se abren ${ }^{47}$.

\section{0.- Caminos sin salida}

En el evangelio de Marcos aparece una sección en la que Jesús enseña, casi en exclusividad, a sus discípulos (Mc 8,27-10,52). Se pueden distinguir tres subdivisiones cada una de ellas compuesta por dos secciones, en las que la primera de ellas está compuesta por tres elementos fijos: anuncio de la pasión, resistencia de los discípulos y enseñanza de Jesús ${ }^{48}$. Efectivamente, a cada uno de los anuncios de la pasión le sigue una reacción de los discípulos que pone de manifiesto su incapacidad para entender y comprender el camino del seguimiento y da pie a una enseñanza del Maestro (Mc 8,32ss; 9,34ss; 10,35ss) ${ }^{49}$. Los discípulos son invitados a replan-

\footnotetext{
${ }^{46}$ Aguirre, Rafael, "Los caminos del Espíritu: Felipe, Pedro y Pablo", 95-97.

${ }^{47}$ Aguirre, Rafael, "Los caminos del Espíritu: Felipe, Pedro y Pablo".

${ }^{48}$ Stock, KLemens, Il camino di Gesú verso Gerusalemme (Mc 8,27-10,52), Editrice Pontificio Istituto Biblico, Roma 1996, 5.

${ }^{49}$ Guijarro, Santiago, El camino de los discípulos, Sígueme, Salamanca 2015, 63.
} 
tearse la forma de seguir a Jesús, al situar estas enseñanzas en el horizonte de la Pascua ${ }^{50}$.

\section{Ponerse delante de Jesús}

Inmediatamente después del primer anuncio del camino de la cruz, Pedro toma a Jesús con vehemencia y le increpa (Mc 8,31-33). Para el discípulo, su maestro está poseído por un espíritu inmundo ${ }^{51}$. Jesús lo coloca detrás de él, el lugar propio del discípulo y exhorta a todo el grupo a permanecer en ese lugar. De esta forma les recuerda y les reenvía al camino del seguimiento ${ }^{52}$. Las aspiraciones, los intereses, los deseos y sentimientos humanos espontáneos, por muy bienintencionados que sean, no concuerdan necesariamente con la voluntad de Dios ${ }^{53}$. En el camino del discipulado tendrán que renunciar a ellos mismos, perder la propia vida para ganarla (Mc 8,34-37). El anuncio de Jesús no encaja con la idea que ellos tienen sobre él y lo que significa ser sus discípulos, algo que se manifiesta claramente en los siguientes episodios, donde se concreta lo que significa negarse a uno mismo, tomar la cruz y perder la vida ${ }^{54}$.

\section{Discutir por el camino}

Tras el segundo anuncio de la pasión, Jesús pregunta a los discípulos: ¿De qué discutíais por el camino?, es decir «Llegaron a Cafarnaún, y una vez en casa, les preguntó: “¿De qué discutíais por el camino?”. Ellos callaban, pues por el camino habían discutido quién era el más importante» (Mc 9,33-34). Los apóstoles no responden. No le abren su corazón. Siguen al Señor solo externamente. Ellos no han aceptado la invitación de "negarse a sí mismo", pero Jesús no los abandona, sino que les dirige una declaración solemne: para ser el primero hay que ser el último y para ello hay que ser el servidor de todos: «Se sentó, llamó a los Doce y les dijo:

${ }^{50}$ Guijarro, Santiago, El camino de los discípulos, 62-63.

${ }^{51}$ La expresión que utiliza el narrador es la misma con la que Jesús se dirige a los demonios en Marcos.

${ }^{52}$ Marcus, Joel, El evangelio según Marcos (Mc 8-16) (=Biblioteca de Estudios Bíblicos 131), Sígueme, Salamanca 2011,694.

${ }^{53}$ Stock, Klemens, Il camino di Gesú,44-48.

${ }^{54}$ Guijarro, Santiago, El camino de los discípulos, 63.65. 
"Quien quiera ser el primero, que sea el último de todos y el servidor de

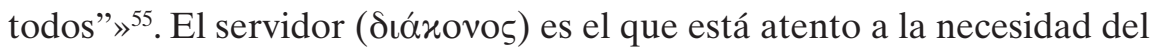
otro como un empeño permanente ${ }^{56}$. Jesús no rechaza su deseo de ser grande, sino el camino que han elegido: el de la autopromoción ${ }^{57}$.

El mismo argumento reaparece con toda su fuerza en la petición de los hijos del Zebedeo de sentarse a su derecha e izquierda en su reino (Mc 10,35-37). Su pretensión irrita y divide al grupo. Jesús, en su respuesta, repite la regla del servicio: «Jesús, llamándolos, les dijo: "Sabéis que los que son reconocidos como jefes de los pueblos los tiranizan, y que los grandes los oprimen. No será así entre vosotros: el que quiera ser grande entre vosotros, que sea vuestro servidor; y el que quiera ser primero, sea esclavo de todos"» (Mc 10,42-44). Enfatiza que entre sus seguidores nadie puede

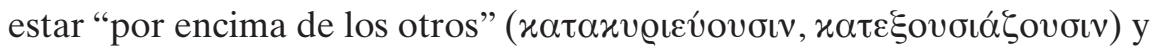

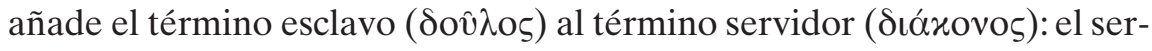
vicio no está ligado a la elección libre del discípulo, sino que es una obligación permanente e indispensable del discipulado ${ }^{58}$.

\section{Cerrar el paso a los pequeños}

No se puede servir si no se acoge a los más pequeños. En Mc 10,1316 los discípulos muestran su torpeza impidiendo e increpando a los que acercan niños a Jesús, ya que les acaba de enseñar la necesidad de recibirlos (Mc 9,33-37) ${ }^{59}$. Los discípulos deben empeñarse y dejar entrar en el ámbito de su propia vida a los más necesitados y vulnerables ${ }^{60}$. Justamente esto representan los niños en este pasaje, en la antigüedad la imagen del niño era su vulnerabilidad, dependencia y la marginalidad social ${ }^{61}$.

${ }^{55}$ Marcus, Joel, El evangelio según Marcos (Mc 8-16),775.

${ }^{56}$ Stock, Klemens, Il camino di Gesú,124-127; Guijarro, Santiago, El camino de los discípulos, 67.

${ }^{57}$ Marcus, Joel, El evangelio según Marcos (Mc 8-16), 778.780; Evangelii Gaudium 98.

${ }^{58}$ STOCK, KLemens, Il camino di Gesú, 158-160; Evangelli Gaudium 95.

${ }^{59}$ Marcus, Joel, El evangelio según Marcos (Mc 8-16), 825.

${ }^{60}$ Stock, Klemens, Il camino di Gesú, 129.

${ }^{61}$ Marcus, Joel, El evangelio según Marcos (Mc 8-16), 825; Evangelii Gaudium 4649.209-216. 
Pretender la exclusividad

Juan Zebedeo cuenta al Maestro cómo han impedido a un exorcista expulsar a un demonio en nombre de Jesús (Mc 9,38-40). Esta es una actividad propia de los Doce (Mc 3,15; 6,7-13), pero que no han sido capaces de realizar (Mc 9,18.28) ${ }^{62}$. La razón de la prohibición es que Juan le dijo: «...se lo hemos querido impedir, porque no viene con nosotros» o literal-

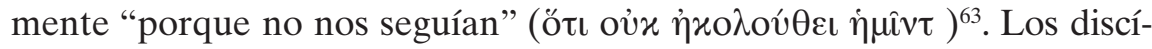
pulos no solo impiden hacer el bien en nombre de Jesús, sino que se erigen en el objeto de seguimiento ocupando el lugar de Jesús.

Una vez más, Jesús les reprende. Los discípulos deben valorar el mínimo gesto de bondad de parte de aquellos que no le siguen ${ }^{64}$. Jesús rechaza tajantemente el exclusivismo e invita a reconocer como un signo de Dios los exorcismos "no oficiales" en medio de la hostilidad predominante ${ }^{65}$.

\section{1.- El ciego Bartimeo. Paradigma de una Iglesia en salida}

Al final del camino hacia Jerusalén aparece la escena de la curación de Bartimeo (Mc 10,46-52). Este episodio presenta características discipulares: se presenta al personaje por el nombre propio del padre y su oficio (Mc 10,35), al igual que en la llamada a los discípulos (Mc 1,19) ${ }^{66}$. Bartimeo evoca la figura de los discípulos: ciego, sentado fuera del camino e incapaz de seguir a Jesús ${ }^{67}$.

En los versículos 47-50 el ciego sentado supera su incapacidad de seguir a Jesús que camina. Bartimeo tiene un deseo irrefrenable de en-

${ }^{62}$ Stock, Klemens, Il camino di Gesú, 158-130; Evangelii Gaudium 94. 131.238-258.

${ }^{63}$ Marcus, Joel, El evangelio según Marcos (Mc 8-16), 783.

${ }^{64}$ Stock, KLemens, Il camino di Gesú, 132.

${ }^{65}$ Marcus descubre una posible alusión en esta escena a que esos exorcistas cristianos no pertenecían al círculo "oficial". No se debe olvidar que Juan fue durante un tiempo una de las columnas de la Iglesia de Jerusalén ( $\mathrm{Gal}$ 2,9) MARCus, JoEL, El evangelio según Mar$\cos ($ Mc 8-16), 783.

${ }^{66}$ Stock, KLemens, Il camino di Gesú,164.170; Marcus, Joel, El evangelio según Marcos (Mc 8-16), 873.

${ }^{67}$ Guijarro, Santiago, El camino de los discípulos, 95. 
contrarse con Jesús, grita reconociendo su mesianidad y se acoge a su compasión. No se rinde ni se deja intimidar ante la increpación de los

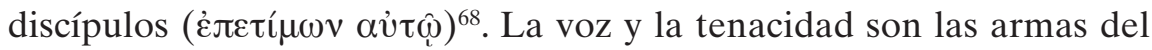
ciego, como la de los niños, de los que son como ellos entran en el Reino de los cielos (Mc 10,32-33) ${ }^{69}$. Para entrar en la lógica divina solo hay un camino: la súplica confiada de quien se sabe incapaz de seguir al Señor por sí mismo; pensar y actuar como Dios es algo que solo Él puede conceder $^{70}$.

Jesús llama al ciego. Este abandona el manto que le cubre en las noches y donde recoge la limosna durante el día, rompe con su vida anterior (Cf. Mc 1,18; 10,50), se levanta y se acerca a Jesús ${ }^{71}$. Bartimeo recibe la misma pregunta que los Zebedeos (Mc 10,36) pero no pide los primeros puestos, sino ver y alcanzar la vida en plenitud que él mismo no se puede $\mathrm{dar}^{72}$. De esta manera se opera el cambio, el ciego camina como discípulo tras Jesús ${ }^{73}$

\section{2.- Conclusión}

La Pascua es el acontecimiento clave para evitar la auto referencialidad de la Iglesia. Debe salir a encontrase con el hombre salido de las manos de Dios, llamado a dar-se y no a ser-se para ser, porque el hombre es transcendencia. Salir al encuentro del hombre en su fragilidad, para juntos hacer salir al mundo, a la casa común, de la explotación, de la destrucción, del caos.

La Iglesia debe realizar una salida en la obediencia de la fe, de liberación, provocada por el Señor, desde el bienestar y la cristiandad para sostenerse solo en Él en la pequeñez y la insignificancia social. Salir como

${ }^{68}$ Son los mismos verbos que utiliza Pedro para dirigirse a Jesús en Mc 8,32 y los discípulos para recriminar a las personas que acercan los niños a Jesús en Mc 10,32.

${ }^{69}$ Stock, Klemens, Il camino di Gesú, 160.

${ }^{70}$ Guijarro, Santiago, El camino de los discípulos, 97.

${ }^{71}$ STOCK, KLEMENS, Il camino di Gesú,167; MARCus, Joel, El evangelio según Marcos (Mc 8-16), 873.

${ }^{72}$ Guijarro, Santiago, El camino de los discípulos, 95.

${ }^{73}$ Stock, Klemens, Il camino di Gesú,165; Marcus, Joel, El evangelio según Marcos (Mc 8-16), 880. 
discípula para acercarse a los nuevos endemoniados de la historia, hablando al corazón del hombre en la palestra de la cultura, la ciencia, la política, la economía, la justicia. Salir del mundo, de la secularización (Ap $18,4)$, sin dejar de estar en el mundo en búsqueda, con toda la humanidad, de los cielos nuevos y la tierra nueva $(2 \mathrm{Pe} 3,13)$. 